\title{
Population Dynamics of Phialophora gregata in Soybean Residue
}

\author{
E. A. Adee, Former Research Associate, and C. R. Grau, Professor, Department of Plant Pathology; and E. S. Op- \\ linger, Professor, Department of Agronomy, University of Wisconsin-Madison, Madison 53706
}

\begin{abstract}
Adee, E. A., Grau, C. R., and Oplinger, E. S. 1997. Population dynamics of Phialophora gregata in soybean residue. Plant Dis. 81:199-203.

Brown stem rot frequently is more severe in no-till cropping systems. Population density of Phialophora gregata was monitored in soybean residue positioned below and on the soil surface. Current season residue was confined in nylon mesh bags that were placed in the field in the fall. Population density of the pathogen was measured monthly through the winter, or seasonally for 30 months, and expressed as CFU per gram of soybean residue. Population dynamics of $P$. gregata differed in surface residue, compared with buried residue. Population density of $P$. gregata was not significantly different in buried and surface residue from November/December to April. Beginning in late April or May, population density of P. gregata was significantly greater in surface residue than in buried residue. The population density of $P$. gregata in surface residue remained above $10^{5} \mathrm{CFU}$ per gram of residue after 30 months in the field. In contrast, the fungus was not detected in buried residue after 11 to 17 months. From November to May, the population destiny of $P$. gregata in surface residue increased more than 14 times the initial density. In contrast, the density of $P$. gregata in buried residue increased sixfold by April, then decreased to densities not significantly different from the initial population by May and June. Mass of buried residue decreased more rapidly than that of surface residue during April, May, and June. There was a positive correlation between residue weight and the population density of $P$. gregata in residue. $P$. gregata survived longer and at higher population densities in residue positioned on the soil surface (simulated no-till) than in buried residue (simulated conventional tillage). Although inoculum density of $P$. gregata remained high in surface residue, total inoculum declined because of loss of residue biomass.
\end{abstract}

Additional keyword: Glycine max

Phialophora gregata (Allington \& D. W. Chamberlain) W. Gams (9) (syn. Cephalosporium gregatum) (3), the causal agent of brown stem rot in soybean (Glycine max L.), is reported to survive saprophytically as mycelium in soybean residue that has been colonized parasitically $(1,3,11,14,17$, 23). Long-term survival structures have not been reported for $P$. gregata $(3,16)$. Thus, decomposition of residue is believed to be an important factor in reducing inoculum density of the pathogen and its threat to soybean productivity. It is not known how inoculum density of $P$. gregata changes within soybean residue positioned below or above the soil surface. Inoculum density of $P$. gregata in soybean residue prior to planting is predictive of brown stem rot severity during the growing season and of soybean yield (1). Thus, control tactics directed at management of pathogen

Corresponding author: C. R. Grau

E-mail: cg6@plantpath.wisc.edu

Current address of E. A. Adee: Northwestern Agricultural Research and Demonstration Center, Monmouth, IL 61462.

Accepted for publication 12 November 1996.

Publication no. D-1996-1216-05R

(C) 1997 The American Phytopathological Society population density in soybean residue may offer solutions to lower the risk of yield loss caused by $P$. gregata.

Research on the saprophytic stage of $P$. gregata has dealt primarily with sporulation on residue and recovery of the fungus from residue. Sporulation of the pathogen was induced on the surface of soybean stems stored in the laboratory at $23^{\circ} \mathrm{C}$ for 10 months, and from stems buried in soil at a depth of $8 \mathrm{~cm}$ for 3 months (14). The fungus was recovered from residue that had overwintered in the field, but did not sporulate on the surface of stems if the outer cortical tissue had disintegrated (11). $P$. gregata has been recovered from residue particles recovered from the soil on a 140$\mu \mathrm{m}$ sieve (11), but not from residue particles passed through a 106- $\mu$ m sieve (19). These findings suggest two possible explanations for the greater severity of brown stem rot in no-till systems (2) and short crop rotations $(2,8,13)$ : (i) the density of $P$. gregata is higher in residue that is less decomposed, and (ii) greater amounts of infested residue remain if residue is not incorporated into soil than if residue is buried. In general, decomposition of crop residue is slower when left on or above the soil surface $(5,7,20)$, but the amount of time needed for soybean residue to decompose in no-till versus conventional till systems has not been reported.
The goal of these experiments was to determine the effects of soybean residue position (in relation to soil surface) on residue decomposition and population density of $P$. gregata. Population density of $P$. gregata in soybean residue was monitored through the winter and through two subsequent growing seasons to determine the role of residue management on the saprophytic phase of the brown stem rot pathogen.

\section{MATERIALS AND METHODS}

Soybean residue decomposition and survival of $P$. gregata in residue parasitically colonized were compared in simulated notill and conventional tillage systems for 30 months in experiments 1 and 2, and every 1 to 2 months from December to June in a third experiment. In experiments 4 and 5 , the population density of $P$. gregata in buried soybean residue was monitored monthly from November through June.

The population density of $P$. gregata was determined by modifying a technique for enumerating CFU of $P$. gregata per gram of soybean stem residue (19). Residue was dried at room temperature for 12 to $18 \mathrm{~h}$ to approximately $85 \%$ dry matter. Residue at this moisture content could be ground with a Wiley mill with a sieve with $0.5 \mathrm{~mm}$ or $0.39 \mathrm{~mm}$ openings. The mill was rinsed with $95 \%$ ethanol and dried with forced air between samples. Ground residue was placed in glass test tubes sealed with two layers of Parafilm "M" (American National Can, Greenwich, CT) and stored at $4^{\circ} \mathrm{C}$ for no more than $48 \mathrm{~h}$ before being processed. A $100 \mathrm{mg}( \pm 5 \mathrm{mg}$ ) subsample of ground residue was added to $9 \mathrm{ml}$ of sterile, distilled water. After agitation for 5 to $10 \mathrm{~s}, 0.5 \mathrm{ml}$ of a $10^{-2}$ or $10^{-3}$ dilution was dispensed onto each of two to three plates per dilution with a Pipetman 1000 (Rainin Instrument Co., Emeryville, CA) fitted with a sterilized pipette tip cut diagonally to enlarge the opening to 1.5 to $3.0 \mathrm{~mm}$, and spread evenly with a sterile glass rod. The dilutant on the surface of the semiselective medium (19) was allowed to dry prior to incubation and the medium was kept out of direct light, since we had observed previously that light altered the medium color, and reduced colony size and intensity of pigmentation of $P$. gregata. The plates were incubated in the dark at $12^{\circ} \mathrm{C}$ for 2 weeks. A second 100 -mg $( \pm 5$ $\mathrm{mg}$ ) subsample of ground residue was dried at $105^{\circ} \mathrm{C}$ for 1 week to determine the dry matter of each sample.

Experiment 1 was conducted at the Walnut St. research gardens, University of 
Wisconsin-Madison campus. Experiment 2 was conducted at the Arlington Agricultural Research Station, Arlington, WI. Soil test results from Walnut St. (Colwood silt loam) were as follows: $\mathrm{pH} 7.4$, organic matter $2.4 \%$, phosphorus 90 ppm, potassium $145 \mathrm{ppm}$, total nitrogen $0.16 \%$. Soil test results from Arlington (Plano silt loam) were as follows: $\mathrm{pH} 7.5$, organic matter $2.4 \%$, phosphorus 65 ppm, potassium $125 \mathrm{ppm}$, total nitrogen $0.14 \%$. Nylon bags with residue from experiment 1 were relocated to the Arlington location after the first growing season. The previous crop grown at both experimental sites was sweet corn (Zea mays L.).

Experiments 1 and 2 involved treatments of the residue in relation to the soil surface (simulated no-till [surface residue] versus conventional till [buried residue]). The source of all soybean residue used in these studies was the lower $25 \mathrm{~cm}$ of the main stem from the brown-stem-rot-susceptible cv. Corsoy 79 collected from fields naturally infested with $P$. gregata. Residue consisted of 40 grams $( \pm 0.5 \mathrm{~g})$ of the lower 25 $\mathrm{cm}$ of mature soybean stems placed in a 30 $\times 30 \mathrm{~cm}$ nylon bag. This amount of residue is equivalent to $4,300 \mathrm{~kg}$ per ha, which corresponds to the upper limit of soybean residue commonly found in fields after harvest $(12,24)$. The bags were constructed by sta-

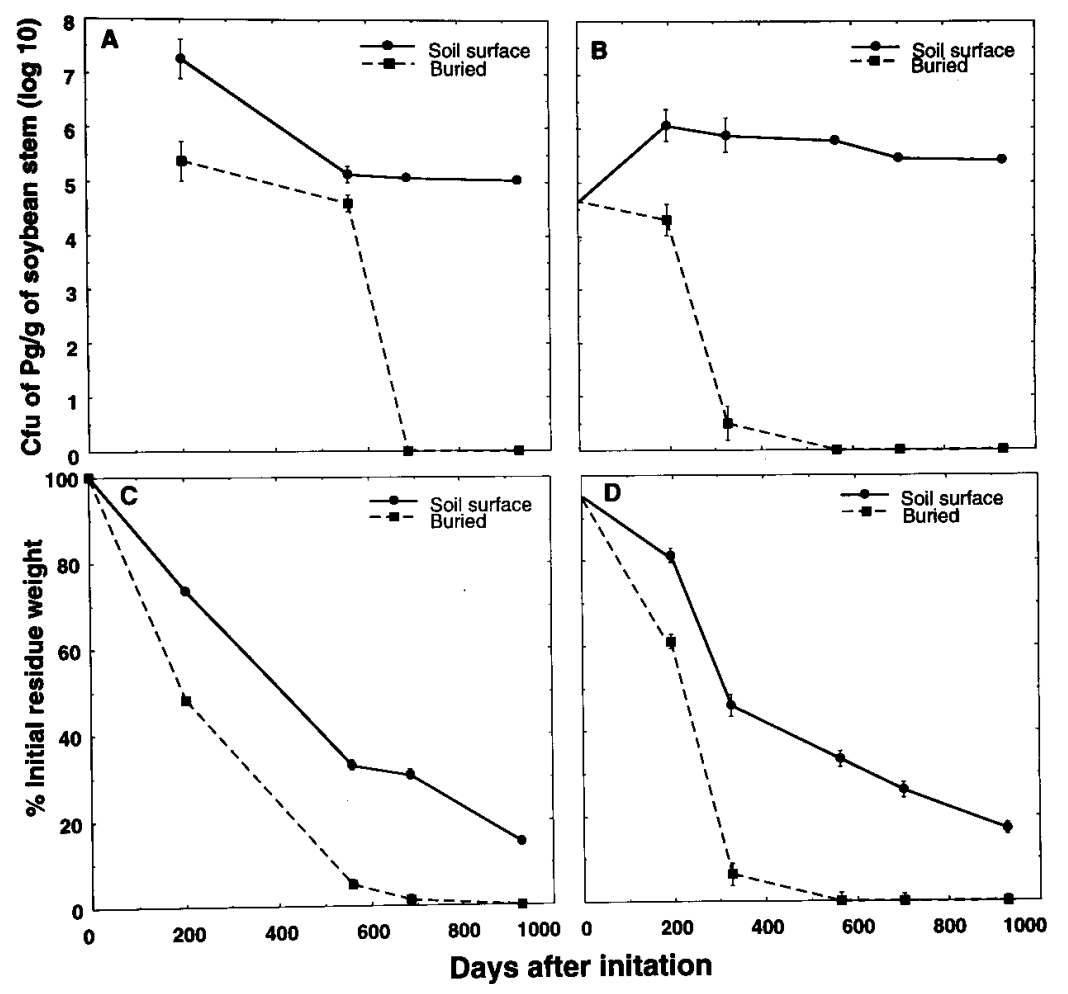

Fig. 1. Population densities of Phialophora gregata $(\mathrm{Pg})$ in soybean residue $(\mathbf{A}, \mathbf{B})$ and percentage of initial residue remaining (C, D) in residue bags placed in the field on 7 November 1989 for experiment $1(\mathbf{A}, \mathbf{C})$ and 7 November 1990 for experiment 2 (B, D). Measurements were made on 29 May 1990, 21 May 1991, 26 September 1991, and 26 May 1992 for experiment 1, and on 21 May 1991, 1 October 1991, 26 May 1992, 12 October 1992, and 25 May 1993 for experiment 2. Values are the means from eight replications in experiment 1 , and 16 replications in experiment 2 . The interaction of residue soil position and sampling date was significant $(P \leq 0.0001)$ for population densities (A, B) and percentage of initial soybean residue remaining (C, D), using repeated measures analysis of variance. Vertical bars represent standard errors of the mean for each sampling date. decomposition and density of the pathogen in residue from the same bags. It had been our experience that variability in the density of the pathogen between individual stems and batches of residue could be high Therefore, we believed repeated measurements from the same residue would be more representative of saprophytic activity of density of $P$. gregata. Previous researchers had found that decomposition rates of leaf litter contained in mesh bags were not altered by repeated (up to 11 times over 12 weeks) artificial drying at $80^{\circ} \mathrm{C}$ for $48 \mathrm{~h}$ (25). Also, residue in the field, especially on the soil surface, goes through repeated wetting and drying cycles. Based on these results and observations, we felt quick rinsing of soil from residue, after which it was allowed to dry briefly at a relatively low temperature, would have minimal influence on the overall population density of the pathogen. A subsample of 1 to $2 \mathrm{~g}$ was taken from either end of 10 randomly selected stem pieces. Stems were assayed for CFU of $P$. gregata per gram of residue. Remaining residue was weighed, returned to the nylon bags, and replaced in the field. Changes in residue weight were adjusted to account for residue removed to determine population densities of $P$. gregata.

Experiment 3 was organized as a two $x$ five factorial randomized complete block design with six replications. Soybean residue was confined between two layers of nylon screen, as described for experiment 1. Residue consisted of four or five stems of the lower $25 \mathrm{~cm}$ of mature soybean stems; i.e., there was $8 \mathrm{~g} \mathrm{(} \pm 2 \mathrm{~g})$ of residue in each $15 \times 30 \mathrm{~cm}$ residue bag. The experiment was conducted at the Arlington Agricultural Research Station. Nylon bags were placed $0.6 \mathrm{~m}$ apart and either buried $20 \mathrm{~cm}$ below the soil surface or placed on the soil surface.

Nylon bags were placed in the field on 3 December 1992 and recovered on 2 February, 27 April, 25 May, and 17 June 1993. Residue weight and population density of $P$. gregata in the residue were quantified at each date by the techniques described above. The entire quantity of residue from each bag collected for each sampling date was processed for quantification of $P$. gregata.

In experiments 4 and $5,15-\mathrm{cm}$-long soybean stems were selected from the lower $30 \mathrm{~cm}$ of the main stems of soybean plants collected from a field where severe foliar symptoms of brown stem rot were observed during the growing season. The initial population density of $P$. gregata for each replication unit of six stems was determined from $2.5-\mathrm{cm}$ subsamples taken from one end of stems. There were 10 replications at each of two locations: experiment 4 was conducted at the Walnut St. research gardens; experiment 5 was conducted at the Arlington Agricultural Research Station.

On 6 November 1991, individual stems were positioned unconfined and vertically 
in the soil at each location. A stem was sampled from each replication at six sampling dates: 9 December 1991, and 7 January, 6 February, 9 March, 13 April, and 1 June 1992. Each stem was rinsed, blotted dry, and allowed to air dry for 18 to $24 \mathrm{~h}$ prior to grinding. The population density of $P$. gregata was determined for each sampling date as described above.

The data for experiments 1 and 2 were analyzed by use of repeated measures analysis of variance in the general linear models (GLM) procedure with SAS (SAS Institute, Cary, NC). For experiment 3, comparisons between treatments were made with the least squares means in the GLM procedure in SAS. Since there were no qualitative interactions involving location, the data of experiments 4 and 5 were combined for analysis. Comparisons between treatments were made with the least squares means in the GLM procedure in SAS.

\section{RESULTS}

The population density of $P$. gregata in surface residue was more than 77 times the population density in buried residue 203 ( $P$ $=0.0004)$ and 195 days $(P=.02)$ after placement in the field (Fig. 1A, B). While the density of $P$. gregata was not measurable in buried residue after 688 days in experiment 1 and 565 days in experiment 2 , the density of the fungus in surface residue remained above $10^{5} \mathrm{CFU}$ per gram of residue. (Fig. 1A, B). In experiment 3 , the population density of $P$. gregata increased in residue at both soil positions. From November through April there was no change in population density of $P$. gregata in buried residue, compared with surface residue (Fig. 2A). However, after April the population density of the fungus decreased in buried residue and increased more than 14 times the initial density in surface residue by 25 May $(P=0.004)$ and 17 June $(P=$ $0.0005)$. The density of $P$. gregata in surface residue on 25 May and 17 June was 7 and 11 times the density in buried residue, respectively (Fig. 2A).

Population density of $P$. gregata increased in buried soybean stems during winter months until April, after which it decreased in the two subsequent samples of May and June (Fig. 3). The population density of the fungus in individual stems, compared with the initial density, was five times greater on 6 February $(P=0.07)$, nine times greater on 9 March $(P=0.002)$, 22 times greater on 13 April $(P=0.0001)$ and four times greater on 1 June $(P=$ 0.04). At the last sampling date (1 June), the density of the fungus was $17 \%$ of the density at the previous (13 April) sampling date $(P=0.006)$. There was not a location effect $(P \geq 0.26)$ on population density of $P$. gregata in experiments.

Buried soybean residue decomposed faster than surface residue at all sampling dates (Fig. 1C, D; Fig. 2B; $P \leq 0.0001$ ).
However, in experiment 3, differences in residue weight between remaining surface and buried residue were not evident until April (Fig. 2B; $P \leq 0.001$ ). The amount of buried residue remaining was 13 to $15 \%$ less, when compared with the amount of surface residue remaining or present at the April, May, and June samplings.

The population density of $P$. gregata was greater in surface residue than in buried residue (Fig. 4). Population density of $P$. gregata correlated to the greater weight of remaining residue after a fall to spring incubation. The percentage of initial residue weight was positively correlated with the population density of $P$. gregata at the spring (May) sampling dates in experiments 1, 2, and 3 (Fig. 3): $r=0.796(P<$ $0.001)$ for experiment $1 ; r=0.73(P<$ 0.001 ) for experiment 2 ; and $r=0.606$ ( $P$ $=0.037$ ) for experiment 3 . Data from residue with densities of the fungus below the detection level were not included in these analyses.

\section{DISCUSSION}

Greater population densities of $P$. gregata were detected in residue left on the soil surface than in buried residue. Al-

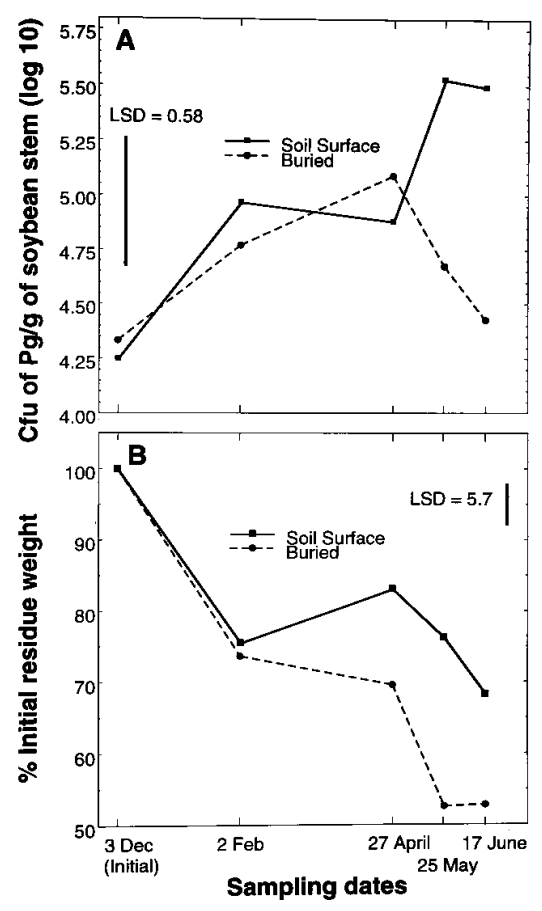

Fig. 2. Population densities of Phialophora gregata $(\mathrm{Pg})$ in soybean residue $(\mathbf{A})$ and percentage of initial soybean residue remaining (B) in residue bags placed in the field on $3 \mathrm{De}-$ cember 1992, and assayed on 2 February 1993, 27 April 1993, 25 May 1993, and 17 June 1993 in experiment 3 . Values are the means from six replications. The interaction of residue soil position and sampling date was significant for (A) population density $(P \leq 0.017)$ and $(\mathbf{B})$ percentage of initial soybean residue remaining $(P=$ $0.0002) . \mathrm{LSD}=$ least significant difference $(P \leq$ $0.05)$, for the interaction of position and sampling date, and is denoted by a vertical bar. though population densities of $P$. gregata increased initially during winter months at all residue positions, populations remained higher in surface residue, compared with declining populations in buried residue, by April and May.

The ability of $P$. gregata to increase in residue has several important implications. Greater population densities of $P$. gregata in surface soybean residue fit a model that greater severity of brown stem rot in no-till systems is related to inoculum potential (1, $2)$. Although crop rotation results in lower severity, the severity of brown stem rot rapidly rises once soybean culture resumes

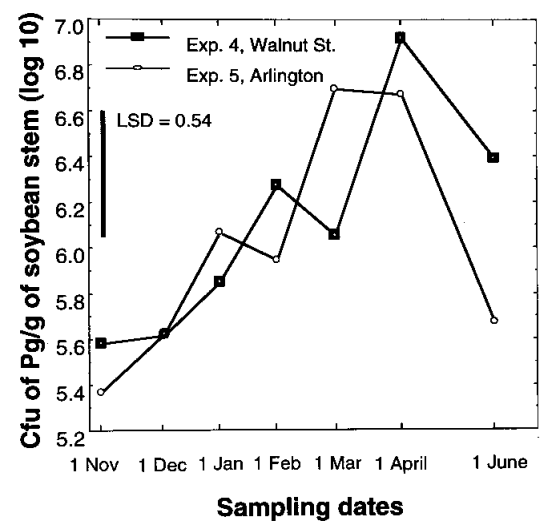

Fig. 3. Population density of Phialophora gregata $(\mathrm{Pg})$ in buried residue and individual soybean stems through the winter. Stems were positioned vertically in the soil on 6 November 1991 and sampled 9 December 1991, 7 January 1992, 6 February 1992, 9 March 1992, 13 April 1992, and 1 June 1992. Values are the means of 10 replications in each experiment. LSD $=$ least significant difference $(P \leq 0.05)$, for the interaction of position and sampling date for the combined analysis of experiments 4 and 5, and is denoted by a vertical bar.

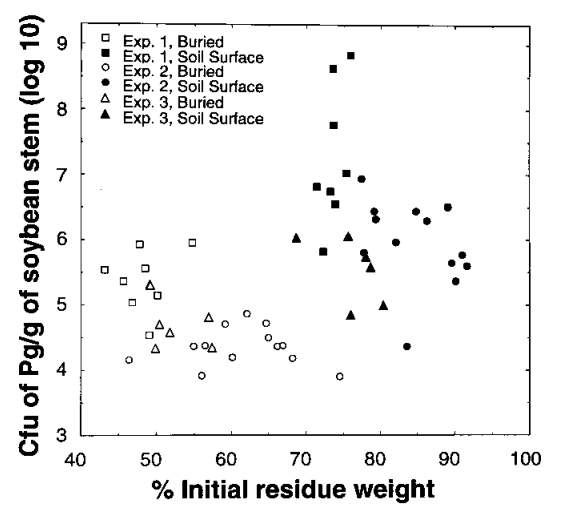

Fig. 4. Correlation between percentage of initial residue remaining and population densities of Phialophora gregata $(\mathrm{Pg})$ in soybean residue when sampled in May after overwintering on the soil surface or buried, in experiments 1,2 , and 3. For experiment $1, r=0.796(P<0.001)$; for experiment 2, $r=0.73(P<0.001)$; and for experiment $3, r=0.606(P=0.037)$. Data from residue with densities of the fungus below the detection density were not included in these analyses. 
after a long crop rotation $(2,8)$. The ability of $P$. gregata to saprophytically increase in soybean residue may partially explain this situation. Predictions of brown stem rot severity and yield loss can be inaccurate if based only on the incidence of brown stem rot in the previous soybean crop because inoculum density of $P$. gregata may increase saprophytically during the nonhost phase of the rotation sequence. Inoculum density of the pathogen in residue at planting is closely correlated with severity of brown stem rot and yield loss that season (1). Visual observations of the severity of brown stem rot in the previous soybean crop may need to be supplemented with data on population density of $P$. gregata in soybean residue near planting time to improve predictions for severity of brown stem rot.

Significant increases in population densities of $P$. gregata during the winter months indicate the saprophytic fitness of this fungus at low temperatures. Ability to grow at low temperatures could give $P$. gregata a competitive edge when utilizing resources at low temperatures during winter and allow it to colonize new tissue saprophytically (22). Although colony development is slow, $P$. gregata has been observed to grow at $4{ }^{\circ} \mathrm{C}$ on a culture medium (19). The ability to predict brown stem severity in subsequent years would be complicated by how well the fungus can colonize crop residue saprophytically at different temperatures and soil moisture conditions.

A decrease in population density of $P$. gregata in May and June in buried residue may partially explain the reduced severity of brown stem rot as planting of soybean is delayed. Grau et al. (10) reported less severe foliar symptoms of brown stem rot in a susceptible cultivar (Corsoy 79) planted on 30 May than when planted on 1 May and 15 May. However, delayed planting results in lower yield potential, and should not be considered as a control tactic for brown stem rot (10).

While decomposition of residue can occur during the winter months, greater differences in decomposition between simulated no-till and conventional tillage were noted in the April to June period. A reduction in population density of $P$. gregata in residue subjected to simulated conventional tillage, compared with no-till, was delayed by one month. However, the average air temperature in April 1993 was $3^{\circ} \mathrm{C}$ cooler than normal and differences in population density between the tillage systems might have occurred earlier if temperatures had been normal.

While confinement of residue in nylon bags is somewhat artificial, it was necessary for these experiments. Residue had to be removed from the field because of limitations in the techniques available to detect the fungus in undisturbed residue. Also, accurately measuring the decompo- sition of the residue was facilitated by the use of nylon bags. Other researchers have found that mesh openings close to $1 \mathrm{~mm}$ have been optimal for reducing artifacts in decomposition rate studies caused by spillage at handling $(15,25)$ and the removal of residue ingested by earthworms (15). The $1.25-\mathrm{mm}$ openings in the nylon screen were large enough to allow contact of soil and soil fauna with the residue confined in the bags.

Contact between soil and crop residue is important in the biology of plant pathogens that are dependent on host residue for survival between crops (6). Pfender and Wootke (21) found that Pyrenophora tritici-repentis (Died.) Drechs. and Septoria nodorum (Berk.) Berk. in Berk. \& Broome, pathogens of wheat (Triticum aestivum L.), survive better in straw positioned above the soil surface than in straw on the soil surface or buried. Cephalosporium gramineum Nisikado \& Ikata in Nisikado et al. produced more propagules in wheat residue left on the soil surface or in the upper $7.6 \mathrm{~cm}$ of soil than in residue that was buried deeper than $7.6 \mathrm{~cm}$ (27). Competition from other saprophytic microorganisms is reported to be enhanced when crop residue is buried $(4,21,22)$. We did not determine the biotic or abiotic factors that influenced the differential survival of $P$. gregata in buried versus surface residue. Knowledge of mechanisms governing population densities of $P$. gregata would have practical and conceptual value.

This study has documented the survival and population dynamics of $P$. gregata in soybean residue and verifies the importance of longer crop rotations to manage brown stem rot. The need for longer crop rotations in a no-till system is indicated by the relatively slow decomposition of surface soybean residue and the greater population densities of $P$. gregata in such tissue. Our data support the need to employ management practices that enhance the decomposition of soybean residue to reduce the inoculum density of $P$. gregata in soybean fields. Resistant cultivars are effective in reducing yield loss to brown stem rot $(17,18)$; however, continued effectiveness of genetic resistance to brown stem rot requires prudent usage to sustain long-term effectiveness against $P$. gregata (26). Thus, management practices are needed to supplement host resistance. With government regulations determining the amount and types of tillage in much of the soybean production area, and the emphasis on reduced tillage practices to control soil erosion and water runoff, longer rotations and residue management that minimize saprophytic growth of $P$. gregata are important to maintain soybean yield in the presence of $P$. gregata.

\section{ACKNOWLEDGMENTS}

We thank James Kurle, Jeff Rumney, and Shelly Adee for their critical review of the manu- script, Beth Hinkens for technical consulting, and Jerry Held, Angie Currie, and Todd Barganz for assistance in conducting these studies. This work was supported in part by CSRS NCR IPM grant 91-34103-5965 and the College of Agriculture and Life Sciences, University of Wisconsin-Madison.

\section{LITERATURE CITED}

1. Adee, E. A., Grau, C. R., and Oplinger, E. S. 1995. Inoculum density of Phialophora gregata related to severity of brown stem rot and yield of soybean in microplot studies. Plant Dis. 79:68-73.

2. Adee, E. A., Oplinger, E. S., and Grau, C. R. 1994. Severity of brown stem rot and soybean yield as influenced by tillage, rotation sequence, and cultivar. J. Prod. Agric. 7:341347.

3. Allington, W. B., and Chamberlain, D. W. 1948. Brown stem rot of soybean. Phytopathology 38:793-802.

4. Baker, K. F., and Cook, R. J. 1974. Biological control of plant pathogens. W. H. Freeman, San Francisco.

5. Christensen, B. T. 1986. Barley straw decomposition under field conditions: Effect of placement and initial nitrogen content on weight loss and nitrogen dynamics. Soil Biol. Biochem. 18:523-529.

6. Cook, R. J., Boosalis, M. G., and Doupnik, B. 1978. Influence of crop residues on plant diseases. Pages 147-163 in: Crop Residue Management Systems. W. R. Oschwald, ed. ASA Spec. Publ. 31. ASA, CSSA, and SSSA, Madison, WI.

7. Douglas, C. L., Jr., Allmaras, R. R, Rasmussen, P. E., Ramig, R. E., and Roager, N. C., Jr. 1980. Wheat straw composition and placement effects on decomposition in dryland agriculture of the Pacific Northwest. Soil Sci. Soc. Am. J. 44:833-837.

8. Dunleavy, J. M., and Weber, C. R. 1967. Control of brown stem rot of soybeans with corn-soybean rotations. Phytopathology 57:114-117.

9. Gams, W. 1971. Cephalosporium-artige Schimmelpilze (Hyphomycetes). Gustav Fischer Verlag, Stuttgart.

10. Grau, C. R., Oplinger, E. S., Adee, E. A Hinkens, E. A., and Martinka, M. J. 1994 Planting date and row width effect on severity of brown stem rot and soybean productivity. J. Prod. Agric. 7:347-351.

11. Gray, L. E. 1972. Recovery of Cephalosporium gregatum from soybean straw. Phytopathology 62:1362-1364.

12. Hanway, J. J., and Weber, C. R. 1971. Dry matter accumulation in soybean (Glycine max (L) Merrill) plants as influenced by N, P, and K fertilization. Agron. J. 63:263-266.

13. Kennedy, B. W., and Lambert, J. W. 1981 Influence of brown stem rot and cropping history on soybean performance. Plant Dis. 65:896-897.

14. Lai, P. Y. 1968. Isolation of Cephalosporium gregatum from soybean straw. Phytopathology 58:1194-1195.

15. Mason, C. F. 1976. Decomposition. Edward Arnold Publishers, London.

16. Mengistu, A., and Grau, C. R. 1986. Variation in morphological, cultural, and pathological characteristics of Phialophora gregata and Acremonium sp. recovered from soybean in Wisconsin. Plant Dis. 70:1005-1009.

17. Mengistu, A., and Grau, C. R. 1987. Seasonal progress of brown stem rot and its impact on soybean productivity. Phytopathology 77: 1521-1529.

18. Mengistu, A., Grau, C. R., and Gritton, E. T. 1986. Comparison of soybean genotypes for resistance to and agronomic performance in the presence of brown stem rot. Plant Dis. 70: 1095-1098. 
19. Mengistu, A., Tachibana, H., and Grau, C. R. 1991. Selective medium for isolation and enumeration of Phialophora gregata from soybean straw and soil. Plant Dis. 75:196199.

20. Parker, D. T. 1962. Decomposition in the field of buried and surface-applied cornstalk residue. F. G. Viets, Jr., ed. SSSA Proc. Vol. 26. ASA, CSSA, and SSSA, Madison, WI

21. Pfender, W. F., and Wootke, S. L. 1988. Microbial communities of Pyrenophora-infested wheat straw as examined by multivariate analysis. Microb. Ecol. 15:95-113.
22. Rayner, A. D. M.,, and Webber, J. F. 1984. Interspecific mycelial interactions-an overview. Pages 383-415 in: The Ecology and Physiology of the Fungal Mycelium. D. H. Jennings and A. D. M. Rayner, ed. Cambridge University Press, Cambridge.

23. Schneider, R. W., Sinclair, J. B., and Gray, L. E. 1972. Etiology of Cephalosporium gregatum in soybean. Phytopathology 62:345-349.

24. Smith, S. J., and Sharpley, A. N. 1990. Soil nitrogen mineralization in the presence of surface and incorporated crop residues. Agron. J. 82:112-116.
25. Suffling, R., and Smith, D. W. 1974. Litter decomposition studies using mesh bags: Spillage inaccuracies and the effects of repeated artificial drying. Can. J. Bot. 52:21572163.

26. Tachibana, H. 1982. Prescribed resistant cultivars for controlling brown stem rot of soybean and managing resistance genes. Plant Dis. 66:271-274.

27. Wiese, M. V., and Ravenscroft, A. V. 1975 Cephalosporium gramineum populations in soil under winter wheat cultivation. Phytopathology 65:1129-1133. 